\title{
Single Coronary Artery, A Coronary Anatomy Anomaly
}

Arzia Pramadi Rahman*, NaharTaufiq, Hariadi Hariawan

Department of Cardiology and Vascular Medicine, Faculty of Medicine, Public Health and Nursing Universitas Gadjah Mada, Yogyakarta, Indonesia

\section{ARTICLE INFO \\ *Corresponding author email: \\ arziarahman@gmail.com \\ address: \\ Jalan Farmako Sekip Utara, \\ Yogyakarta, 55281 \\ Indonesia}

\section{Keywords:}

single coronary artery; anomaly; anatomy; intervention cardiology

Manuscript submitted: May 4, 2020

Revised and accepted: August 6, 2020

\begin{abstract}
Coronary artery anomaly and variation is a group of congenital abnormality of the coronary artery with a wide variety of clinical manifestations. The cases are rare and usually found incidentally, but they become interesting because they are the second most causes for sudden cardiac death (SCD) in young adults participating in competitive sports. The number of cases of coronary artery anomaly is starting to rise as the number of cases undergoing invasive and non-invasive diagnosis procedure. Single coronary artery is a very rare congenital anomaly where there is only one coronary ostium to supply the whole heart. This anomaly usually occurs with other congenital anomaly. The symptoms may be unspecific from asymptomatic until SCD. This case report discusses about a patient with single coronary artery, its clinical approach, and the treatment options.
\end{abstract}

\section{INTISARI}

Anomali dan variasi arteri koroner merupakan kelompok kelainan kongenital arteri koroner dengan variasi dan manifestasi klinis yang cukup luas. Meskipun kasusnya relatif jarang dijumpai dan biasanya ditemukan secara tidak disengaja, kasus anomali dan variasi arteri koroner cukup menarik perhatian karena menjadi penyebab kematian mendadak terbanyak ke-2 pada dewasa muda yang berpartisipasi dalam olahraga kompetitif. Anomali arteri koroner mulai lebih sering dijumpai seiring meningkatnya jumlah pasien yang menjalani prosedur diagnosis invasive maupun pencitraan noninvasive. Arteri koroner tunggal merupakan anomali kongenital yang jarang dijumpai dimana hanya terdapat satu arteri koroner yang berasal dari satu ostium koroner untuk mengaliri seluruh jantung. Anomali ini biasanya disertai dengan adanya anomali kongenital yang lain. Gejala yang dijumpai pada pasien dengan arteri koroner tunggal sangat bervariasi, dari gejala yang ringan dan tidak spesifik sampai dengan sudden cardiac death (SCD). Pada laporan kasus ini kami membahas mengenai kasus anomali anatomi koroner berupa arteri koroner tunggal, pendekatan klinis serta pilihan penatalaksanaannya.

\section{Introduction}

Anomaly and variation of the coronary artery is a group of congenital abnormality of the coronary artery with a wide variety of clinical manifestations. The cases are rare and usually found incidentally, but they become interesting because they are the second most causes for sudden cardiac death (SCD) in young adults participating in competitive sports. ${ }^{1}$ This coronary anomaly is usually found incidentally during diagnostic procedures or postmortem examinations, with the prevalence of $0.019-0.4 \%$ of general population, and $<3 \%$ of the whole coronary anomaly group. ${ }^{2,3}$ The symptoms may be unspecific from asymptomatic until SCD. ${ }^{4}$ The treatment options may be conservative medical treatment, percutaneous coronary intervention (PCI) with stenting, or surgical correction. ${ }^{5}$ This case report discusses about a patient with single coronary artery, its clinical approach, and the treatment options.

\section{Case Presentation}

An 83 year-old woman was referred to the Cardiology Outpatient Clinic of Dr. Sardjito General Hospital with a 
main complaint of having a chest pain. The patient was referred from a private hospital with a diagnosis of stable angina pectoris. 3 months prior to admission the patient started to complain about having chest pain which happens during her activity and ceases at rest. The patient denies any shortness of breath, dizziness, syncope, cold sweats, nausea, or vomiting. The patient was then brought to a private hospital to have a checkup where she was diagnosed to have a coronary artery disease and was suggested to be referred and have a catheterization at Sardjito General Hospital.

The patient had a history of hypertension with the highest blood pressure having to be $180 \mathrm{mmHg}$, while her usual blood pressure is $130 \mathrm{mmHg}$. The patient also had a history of diabetes and dyslipidemia. The patient never smoked before, is already in menopause, and does not have any family members having history of heart attack. The patient routinely has a checkup in the Cardiology Outpatient Clinic and is on routine treatment with clopidogrel $75 \mathrm{mg}$ q.i.d, atorvastatin $40 \mathrm{mg}$ q.i.d, bisoprolol $2.5 \mathrm{mg}$ q.i.d, and glimepiride $3 \mathrm{mg}$ q.i.d.

On physical examination, her blood pressure was 130/80 $\mathrm{mmHg}$, regular heart rate 75 beats per minute, respiratory rate 20 times per minute, temperature 36.5 degrees Celsius, and oxygen saturation to $98 \%$ with room air. Jugular Venous Pressure (JVP) 5+2 cmH2O. On chest examination the apex was found on the 5 th intercostal space with normal heart sounds on auscultation. Other physical examinations were in normal range.

The electrocardiogram on admission (Figure 1) showed a sinus rhythm with a heart rate 56 times per minute, normal axis, with pathological $\mathrm{Q}$ wave on lead V1 to V4. The chest $\mathrm{x}$-ray on anteroposterior supine position shows cardiomegaly with CTR 0.56 and aortosclerosis (Figure 2).

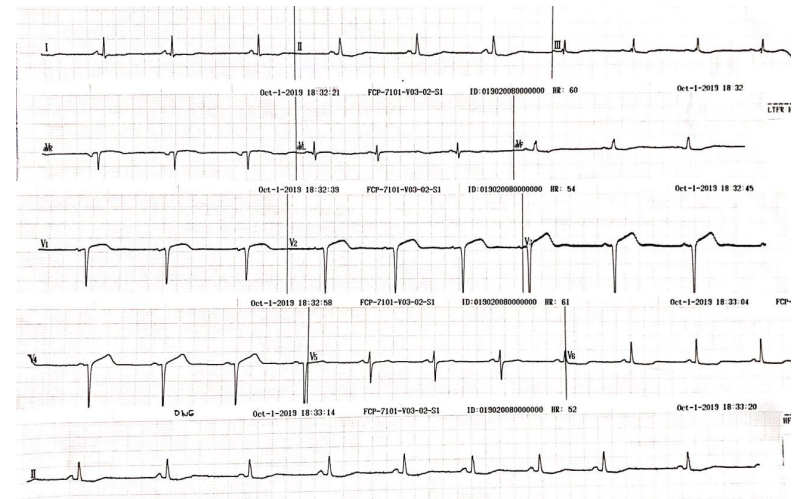

Figure 1. Patients ECG on admission. Normal sinus rhythm, 56 beats per minute, normal axis, pathological Qwaves at lead V1-V4.

To evaluate the function and structure of the heart, the patient underwent an echocardiography. The results show the normal dimension of heart chambers with concentric hypertrophy. The ejection fraction was $53 \%$ and there was a hypokinetic segment at the basal-mid inferoseptal and basal-mid anterior segment. The structure and function are the heart valves were still normal.

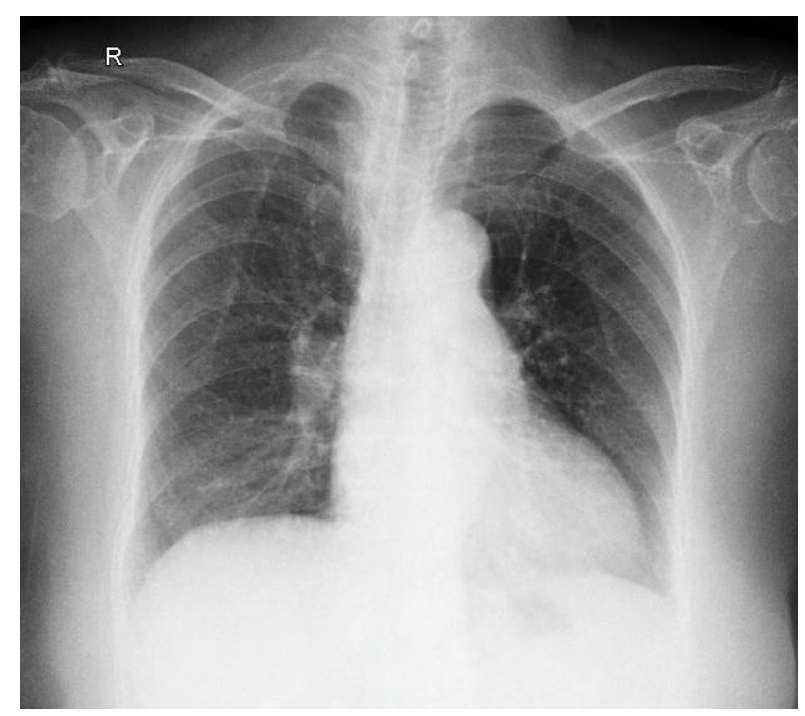

Figure 2. Patients chest x-ray on admission.

Anteroposterior supine position, cardiomegaly with CTR 0.56 and aortosclerosis.

The patient then underwent a coroangiography (CAG) which revealed the patients coronary arteries (Figure 3-8). The Left Main (LM) was short with 30\% distal stenosis; the Left Anterior Descending (LAD) had some ostial plaque with $70-90 \%$ proksimal-distal stenosis and calcification. The Left Circumflex (LCx) had 70\% ostial stenosis with poststenotic dilatation. The LCx was large and dominant, extending to the territory of the Right Coronary Artery (RCA). The ostial of the RCA was not visual even though an aortography was done. Based on this CAG, it was concluded that the patient had CAD-2VD with LM stenosis (Medina 1-1-1), single coronary ostium (LM-LCA), without RCA ostium.

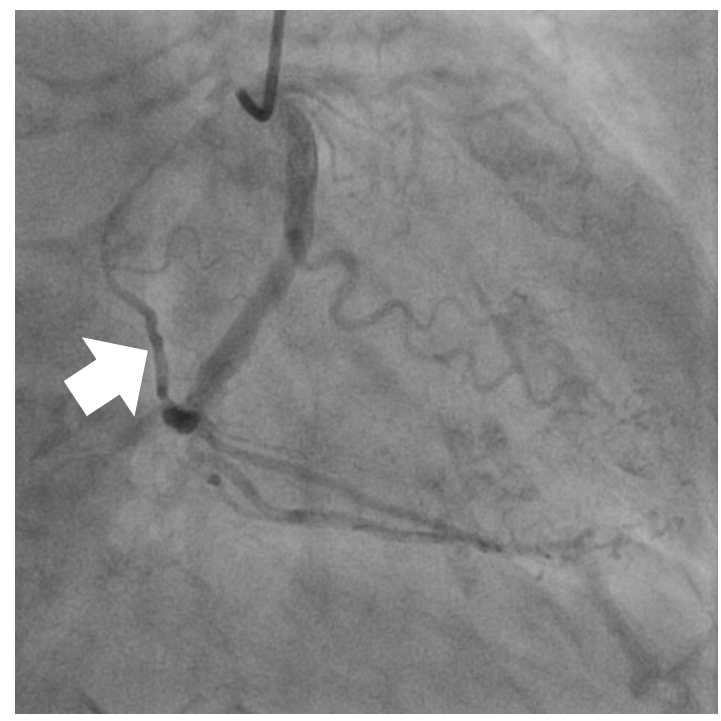

Figure 3. View RAO Caudal, short LM, the LAD andthe LCx. LCxgiving supply to the RCA territory (arrow) 


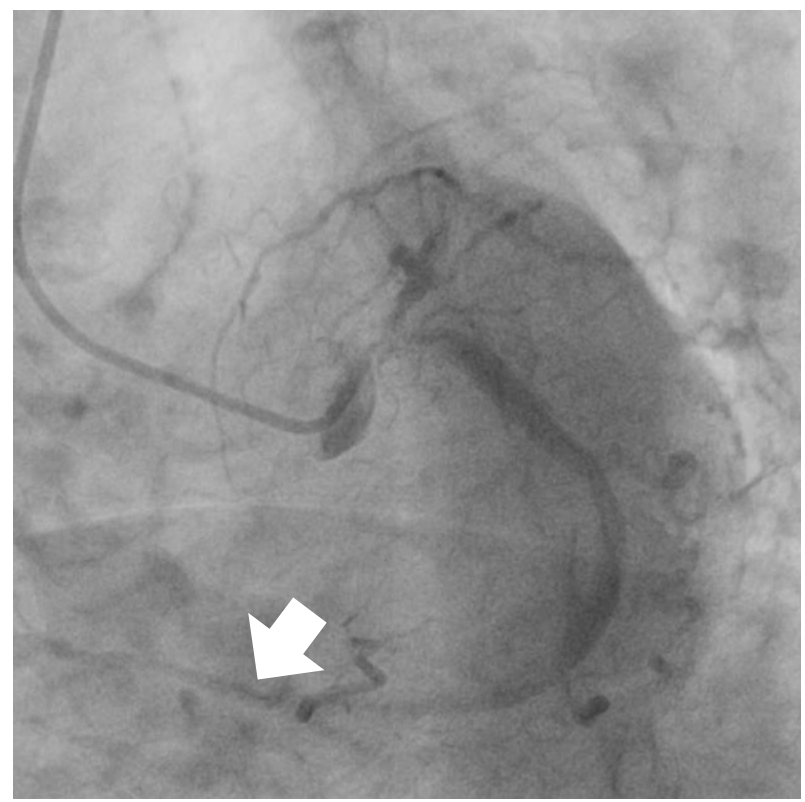

Figure 4. View LAO Caudal(Spider), short LM, the LAD and the LCx. LCx giving supply to the RCA territory (arrow)

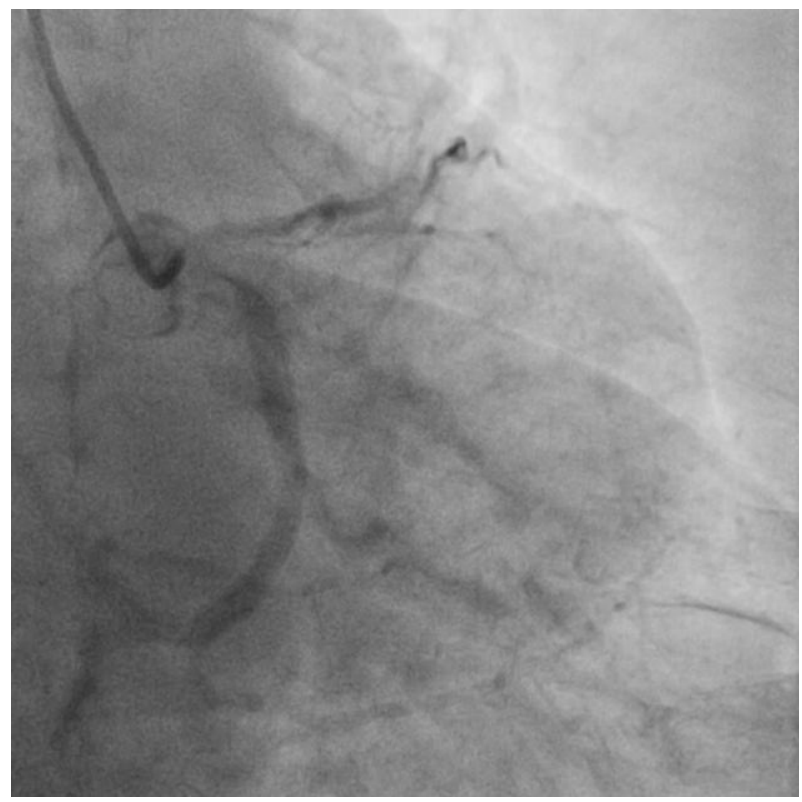

Figure 5. View RAO Cranial, short LM, the LAD and the LCX.

A cardiac multi-slice computed tomography (MSCT) with contrast was conducted to get the full evaluation of the coronary anatomy and to seek for other congenital heart comorbids that might occur. The results showed a left dominant coronary artery and agenesis of the RCA. There was no anomaly of LM ostium or any high take-off, and there was no myocardial bridging. There was an aortosclerosis of the aortic arch and the thoracic descending aorta. The findings in the MSCT supported and confirmed the findings from other previous examinations.

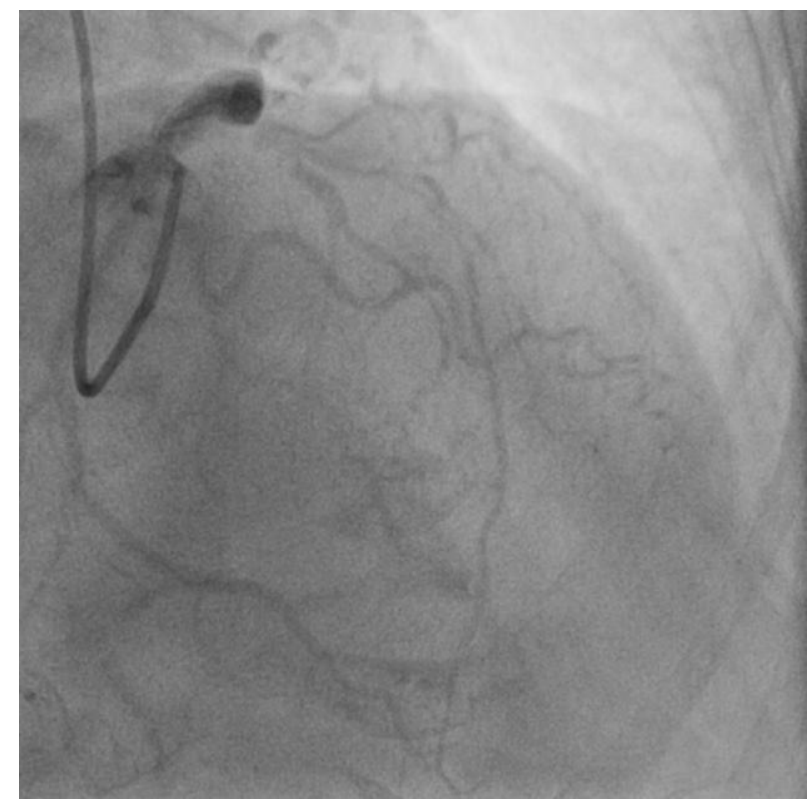

Figure 6. View LAO Cranial, short LM, the LAD and the LCx.

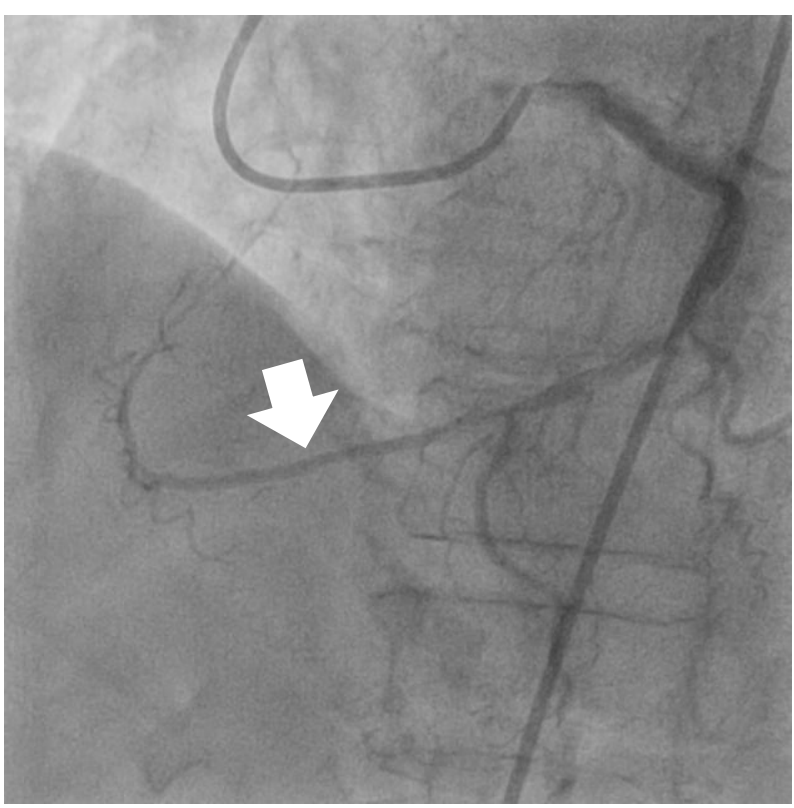

Figure 7. View LAO Cranial, focusing on the route of LCx giving supply to the territory of the RCA (arrow)

\section{Discussion}

Anomaly and variation of the coronary artery is a group of congenital abnormality of the coronary artery with a wide variety of clinical manifestations. The cases are rare and usually found incidentally, but they become interesting because they are the second most causes for SCD in young adults participating in competitive sports. We need to distinguish the normal variants of the coronary artery from the coronary artery anomalies. A certain morphological feature of the coronary artery anatomy is considered as a normal variant if the prevalent of the structure in $>1 \%$ of the general population. The 
prevalence of single coronary artery is $<1 \%$ hence it is considered as an anomaly of the coronary artery. ${ }^{1}$

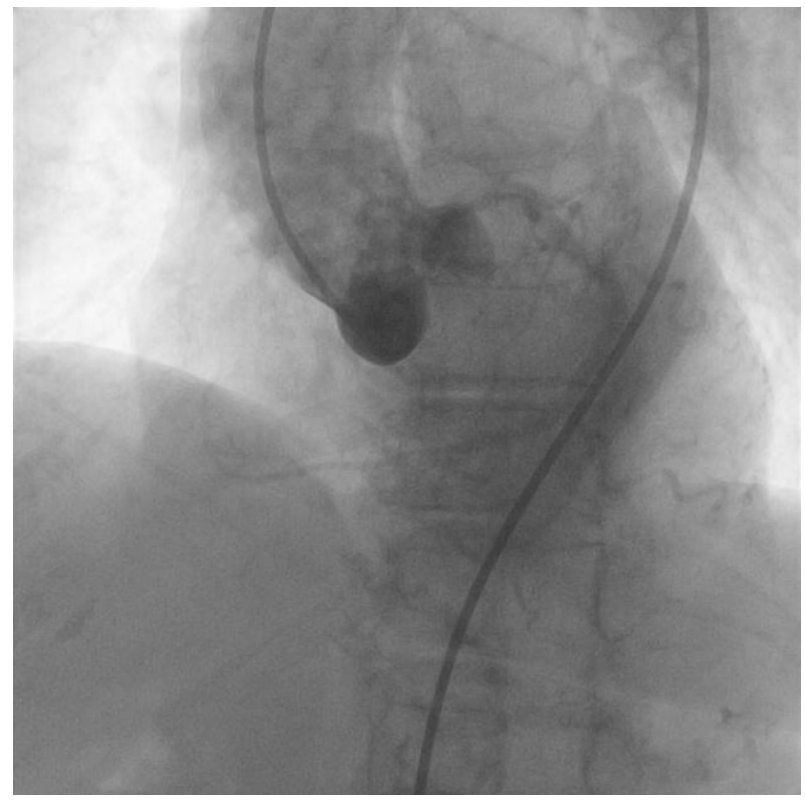

Figure 8. AO graphy, no ostium of the coronary arteryarising from the right sinus of valsalva (arrow)

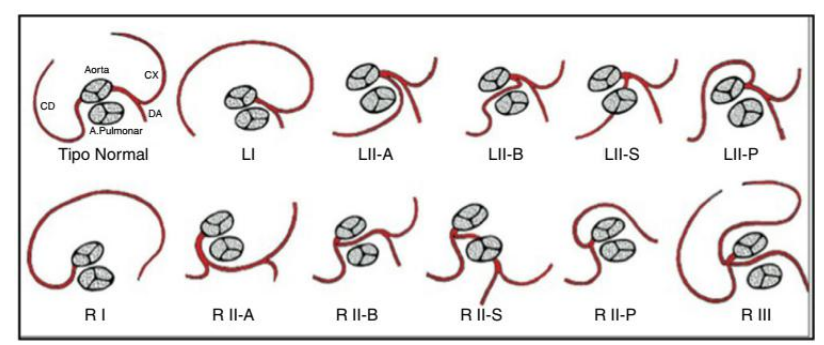

Figure 9. Lipton et al classification for single coronary artery $^{8}$

There are some case reports about single coronary artery with several anatomical variations. This coronary anomaly is usually found incidentally during diagnostic procedures or post-mortem examinations, with the prevalence of $0.019-0.4 \%$ of general population, and $<3 \%$ of the whole coronary anomaly group.,3 About $15 \%$ of patients with single coronary artery have severe heart disease before the age of 40 years old. The mortality rate is pretty high, reaching $59 \%$, before the age of 20 years old. ${ }^{6}$ Single coronary artery can arise from the left or the right sinus of valsalva and may be accompanied with other congenital anomalies. A study that included 142 patients with single coronary artery and other congenital anomalies reported that $49 \%$ of the single coronary artery arise from the right sinus of valsalva, $45 \%$ arise from the left sinus of valsalva, and the rest arised from the pulmonary trunk or other anomalies. ${ }^{4}$ Lipton et al formed a classification for single coronary artery (Figure 9) based on its ostium (R: right sinus of valsalva, L: left sinus of valsalva), anatomical distribution (I: Single coronary artery with the normal route of the LCA or RCA, II: coronary artery with abnormal ostium that arises from the proximal segment of the contralateral coronary artery, III: single coronary artery with the ostium that arises from the right sinus of valsalva with LAD and LCx that branches from the same proximal segment of the RCA), and the route of the aberrant coronary artery (A: through the anterior part of the great arteries, B: through the route between the aorta and the pulmonary artery, P: through the posterior part of the great arteries, S: through the septal, C: combination routes). Based on the Lipton et al classification, the patient in this case is classified into LI where the single coronary artery arises from the left sinus of valsalva and the $\mathrm{LCx}$ takes its normal route and continues to the territory of the RCA. ${ }^{1,5,7,8}$

In cases with single coronary artery that arises from the left sinus of valsalva, the RCA may arise from the proximal or the mid segment of the LAD and take the route through the anterior part of the pulmonary artery or through the route between the aorta and the pulmonary artery heading towards the right atrioventricular groove. The prevalence of this anomaly is $0.024 \%-0.066 \%$ of the general population. This anomaly is usually benign, especially if the RCA does not go through between the aorta and the pulmonary artery where it may cause myocardial ischemia or SCD. In very rare cases the RCA may be supplied by the distal LCx. ${ }^{1,9}$

In cases with single coronary artery that arise from the right sinus of valsalva, the LCA may take the route on the anterior or between the aorta and the pulmonary artery towards the territory that it is supposed to supply. The prevalence of this anomaly is $0.02 \%-0.05 \%$ of the general population, and is more often related with SCD compared with the single coronary artery arising from the left sinus of valsalva, especially those with interarterialroute. ${ }^{5}$

Besides the classification by Lipton et al, there is a new classification proposed by Shirani and Roberts that predicts all the possible anatomical anomaly that might happen, even though there has never been a report about such coronary anatomy before. The ostium that arises from the left sinus of valsalva is classified into type I, while the ostium that arises from the right sinus of valsalva is classified into type II. Based on the classification of Shirani and Roberts, the patient in this case report is classified into single coronary artery type IA. Shirani and Robert's classification of single coronary artery has not been used widely. ${ }^{4}$

The symptom that was found in patients with single coronary artery has a wide range of variations, being mild and on specific up to a SCD. Many patients complained of having non-specific chest pains, syncope, palpitation, symptoms of heart failure, ventricular tachycardia, or even symptoms of myocardial ischemia and SCD. severe symptoms up to SCS is usually related with the route of the single coronary artery that goes through the interarterial route after branching from the proximal segment of its contralateral coronary artery. The pathophysiology is based on the dilatation of the outflow track into the great arteries during exercise which causes a secondary compression to the coronary artery anomaly that goes 
through between the inter-arterial routes. Taylor et al did a research on 242 medical records of patients with coronary artery anomaly which has died, and the reported that $33.3 \%$ died because of SCD, and $50 \%$ of them happened during exercise especially in patients younger than 30 years old. Autopsy on athletes which had SCD and coronary artery anomaly showed that $80 \%$ of the coronary artery anomaly had the route between the great arteries. Coronary anomaly was related with $12 \%$ of SCD that happens during exercise and $1.2 \%$ of SCD during nonexercise activity, indicating that coronary anomaly is very lethal during exercise or a few moments after exercise.4 The patient in this case started to complain about chest pain which comes and goes, especially happens during activity and ceases at rest since the last 3 months. The symptom or complaint is appropriate with the symptoms that is found in patients with single coronary artery that does not go through that inter-arterial route. ${ }^{10}$

The electrocardiogram in patients with a single coronary artery is usually normal. The abnormality of electrocardiogram is usually present if the patient has had a structural remodeling or ischemia and infarction. A stress test electrocardiogram may be an option of examination in patients with a single coronary artery before an invasive or a more sophisticated diagnostic procedure is done. ${ }^{2}$ Coronary angiography (CAG) is the gold standard of diagnosis and classification for patients with coronary artery anomaly. The anomaly of the coronary artery route is best assessed with the view RAO $30^{\circ}$ in through the "dot and eye" method, even though sometimes it is still difficult and need other views as well. ${ }^{4}$ Echocardiography may be very helpful to assess the structure and function of the heart. Other imaging modalities such as cardiac MSCT and Cardiovascular Magnetic Resonance (CMR) is an alternative to evaluate the anatomical anomaly of the coronary artery. ${ }^{11,12,13,14}$

This patient has went through a CAG which reported that the patient had CAD-2VD with LM stenosis (Medina 1-1-1), single coronary ostium (LM-LCA), without RCA ostium. The patient also had a cardiac MSCT with contrast that confirmed a left dominant coronary artery and agenesis of the RCA. There was no anomaly of LM ostium or any high take-off, and there was no myocardial bridging. There was an aortosclerosis of the aortic arch and the thoracic descending aorta. The findings of single coronary artery and coronary artery disease in these examinations explained why the patient had symptoms of stable angina pectoris.

The treatment options for patients with single coronary artery are conservative medical treatment, percutaneous coronary intervention (PCI) with stenting, or surgical correction. Asymptomatic patients do not need invasive treatment and only need to have strict control of their risk factors. The variety of coronary artery anomaly is very vast, hence a multi-discipline approach from cardiothoracic surgery and interventional cardiology is needed to decide the best treatment option for patients with symptoms. There is a big challenge for interventional cardiologist to do the primary PCI in patients with a single coronary artery that happened to experience acute coronary syndrome (ACS). Some reports about single coronary artery which underwent successful PCI with stenting have been reported. Surgical treatment options include osteoplasty, coronary artery bypass grafting (CABG) for the coronary artery anomaly, and reimplantation of the coronary artery anomaly to the aorta. ${ }^{15,16,17,18}$ There has not been an official guideline for treatment in patients with coronary anomaly because of the rare number of patients reported with this condition and the wide variety of cases, hence every case of coronary anomaly has to be analyzed and treated individually based on its coronary anomaly characteristics. ${ }^{6}$ In this patient, we decided to give a conservative medical treatment because of the minimal symptom and we can still control the risk factors. Besides that, the patient's age which is 83 years old need to be considered if an invasive intervention what's going to be the choice of treatment.

\section{Conclusion}

We report an 83 year-old woman with single coronary artery arising from the left sinus of valsalva and agenesis of the RCA, having the LCx to give supply to the territory of the RCA. Single coronary artery is a very rare congenital lanomaly where there is only one coronary artery which arise from one coronary ostium to supply the whole heart. The manifestation of a single coronary artery may be from asymptomatic until a sudden cardiac death, which is related with the route of the coronary artery anomaly going between the great arteries. The treatment options are conservative medical treatment, PCI with stenting, or surgical correction which is chosen based on the patient's clinical condition.

\section{References}

1. Angelini P. 2007. Congenital heart disease for the adult cardiologist, coronary artery anomalies: an entity in search of an identity. Circulation, 115:12961305.

2. Yaymaci B, Ururlucan M, Basaran M, Selimoglu O, Kocailik A, Akyildiz A, et al. 2010. Case report: solitary coronary artery nourishing the entire heart. Ann Saudi Med, 30:81-83.

3. Nunes MBG, Duarte SI, Moreno RAM, Filho AC, Lamas ES, Braga SN. 2014. Anomalous origin of the right coronary artery from the mid-left anterior descending artery: a rare coronary anomaly. Rev Bras Cardiol Invasiva, 22:300-302.

4. Graidis C, Dimitriadis D, Ntatsios A, Karasavvidis V, Psifos V. 2013. Percutaneous coronary intervention and stenting in a single coronary artery originating from the right sinus of valsalva. Hellenic J Cardiol, 54:401-407.

5. Kastellanos S, Aznaouridis K, Vlachoupoulus C, Tsiamis E, Evangelos O, Tousoulis D. 2018. Overview of coronary artery variants, aberrations and anomalies. World J Cardiol, 10:127-140. 
6. Yokohama HAR, Pessoa CMA, Carvalho FC, Campos RF, Franco RJS, Bregagnollo EA. 2007. Percutaneos coronary intervention in single coronary artery in a patient with high risk unstable angina. Arq Bras Cardiol, 88:e51-e53.

7. Mohanty A. 2015. A review on single coronary artery. Imaging Med, 7:19-20.

8. Neiva J, Silva MP, Pires-Morais G, Dias A, Ponte M, Caeiro D, et al. 2019. Right single coronary artery as an incidental finding in Takotsubo syndrome and acute heart failure: Case report and review of the literature. Rev Port Cardiol, 38:215-223.

9. Mihl C, Alzand BSN, Winkens MH. 2010. Case report: a rare coronary anomaly: one ostium fits all. Cardiol Res Pract. 2010 Jul 20;2010:476760..

10. Elbadawi A, Baig B, Elgendy IY, Alotaki E, Mohamed $\mathrm{AH}$, Barssoum K, et al. 2018. Single coronary artery anomaly: a case report and review literature, Cardiol Ther, 7:119-123.

11. Chow B, Ling Michael, Ascah K. 2009. Single coronary artery in a patient with apical variant hypertrophic cardiomyopathy. Can J Cardiol, 25(6):e205.

12. Kim DY, Kim HW. 2017. Single coronary ostium in a patient with quadricuspid aortic valve combined with aneurysmal ascending aortic dilatation. J Cardiothorac Surg, 12:59.

13. Umairi R, Al-khouri M. 2019. Prevalence, spectrum, and outcomes of single coronary artery detected on coronary computed tomography angiography (CCTA). Radiol Res Pract, 2019:2940148.

14. Aldana-Sepulveda N, Restrepo CS, Kimura-Hayama E. 2013. Single coronary artery: Spectrum of imaging findings with multidetector CT. J Cardiovasc Comput Tomogr, 7:391-399.

15. Corbett M, Powers J, King S, Quinn M, Harris D. 2009. Single coronary artery. J Am Coll Card, 53:5.

16. Abdulshakour BM, Saeed M, Taher MM, 2019. Anomalous coronary artery anatomy with a single coronary ostium arising from the right coronary: a case report and literature review. Int Med Case Report J, 12:135-141.

17. Fu F, Jin H, Feng Y. 2015. A rare case of single right coronary artery with congenital absence of left coronary artery in an adult: a case report. J Cardiothorac Surg, 10:57.

18. Prifti E, Ademaj F, Krakulli K, Rruci M, Zeka M, Demiraj A. 2016. A rare coronary anomaly consisting of a single right coronary ostium in an adult undergoing surgical coronary revascularization: a case reort and review of the literature. J Med Case Rep, 10:190. 